軽金属 第69巻 第1号 (2019), 9-14

\title{
高強度・高勒性アルミニウム合金の開発
}

\author{
森 久史 ${ }^{1 *} \cdot$ 箕田 正 $^{1} \cdot$ 尾村 直紀 ${ }^{2} \cdot$ 戸次 洋一郎 ${ }^{1}$
} 兒島 洋一 ${ }^{1} \cdot$ 渡辺 良夫 ${ }^{1} \cdot$ 田中 宏樹 ${ }^{1,2}$

Journal of The Japan Institute of Light Metals, Vol. 69, No. 1 (2019), 9-14

(C) 2019 The Japan Institute of Light Metals

\section{Development of high-strength and high-toughness aluminum alloy}

\author{
Hisashi MORI ${ }^{1 *}$, Tadashi MINODA ${ }^{1}$, Naoki OMURA ${ }^{2}$, Youichiro BETSUKI ${ }^{1}$, \\ Yoichi KOJIMA ${ }^{1}$, Yoshio WATANABE ${ }^{1}$ and Hiroki TANAKA ${ }^{1,2}$
}

Keywords: aerospace application; aluminum alloy; strength; toughness; microstructural control

\section{1. 緒言}

航空機，鉄道車両および自動車等の輸送機器に対し， $\mathrm{CO}_{2}$ 排出量のさらなる削減が求められており, その対策として, 機体，構体および車体の省エネ化，軽量化が積極的に進めら れている ${ }^{1), 2)}$ 。表 1 に航空機の機体材料としての要求特性を 示す。航空機では，機体に先進複合材 (CFRP) が適用され つつあり，剛性確保とともに軽量化が進められている ${ }^{3)} 。 し$ かし，CFRPは材料自体のコストが高いほかに，大型の一体 成形が困難であること，金属との接合によるガルバニック腐 食の発生，金属材料の適用では問題にならなかった耐落雷性

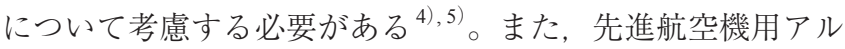
ミニウム合金として開発が進められている Al-Li合金には, $\mathrm{Li}$ の活性化により製造が難しいこと，勒性が低いことや 2 次 加工が難しいなどの課題が多く認められる ${ }^{5), 6)}$ ため, 航空 機製造メーカでは, 汎用性および使用実績を考慮し，現行で 使用されている高強度アルミニウム合金（7000系）の高性 能化に対する期待が高まっている。

現在, 航空機機体向け7000系アルミニウム合金の産業は,
海外のアルミニウムメーカが $90 \%$ 以上のシェアを占めており， 国内調達材の適用が難しい分野でもある。そこで, 本研究の 未来開拓プロジェクト「高強度・高勒性アルミニウム合金の 開発」では, 次世代航空機用アルミニウム合金の国内調達の 拡大を目標とし，図1に示すように伸び（勒性）を維持しな がら強度に優れ, さらに高い耐食性を示すアルミニウム合金 およびそのプロセス技術を開発することを目的としている。

本報では, 実施項目の簡単な概要を説明し, 各項目の主要 な研究成果について紹介する。

\section{2. 研究開発項目}

$\mathrm{Al}-\mathrm{Zn}-\mathrm{Mg}-\mathrm{Cu}$ 合金の機械的特性は，化学成分，熱処理組

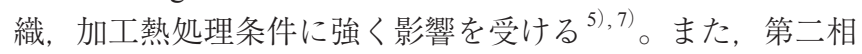
粒子を微細分散化して高強度化するための新たなプロセス手 法の適用も考えられる。本研究では, 下記の項目を設けて研 究を実施している。

・高強度・高䩔性を示す最適合金設計

・鋳塊の水素ガス低減と電磁擋拌手法による鋳塊組織微細化 手法

表 1 航空機用機体材料の特性

\begin{tabular}{|c|c|c|c|c|}
\hline & 本研究開発 & $\mathrm{Al}-\mathrm{Li}$ & CFRP & 現行材 (7150) \\
\hline 特性值（品質） & $\begin{array}{l}\text { 比強度 }{ }^{+} \\
\text {比剛性 } \bigcirc \\
\text { 異方性 } \bigcirc \\
\text { 衝撃性○ }\end{array}$ & $\begin{array}{l}\text { 比強度 } \bigcirc \\
\text { 比剛性 }{ }^{+} \\
\text {異方性 } \triangle \\
\text { 衝撃性○ }\end{array}$ & $\begin{array}{l}\text { 比強度@ } \\
\text { 比剛性@ } \\
\text { 異方性 } \times \\
\text { 衝撃性× }\end{array}$ & $\begin{array}{l}\text { 比強度 } \bigcirc \\
\text { 比剛性 } \bigcirc \\
\text { 異方性 } \bigcirc \\
\text { 衝撃性 } \bigcirc\end{array}$ \\
\hline コスト（現行材比） & 1.5倍目標 & 2-4倍 & 10 倍以上 & 1 \\
\hline 生産性 & $\bigcirc^{-}$ & $\triangle$ & $\triangle$ & $\bigcirc$ \\
\hline 安全性（製造時） & 0 & $\triangle$ & $?$ & 0 \\
\hline
\end{tabular}

\footnotetext{
${ }^{1}$ 株式会社UACJ（广455-8670 愛知県名古屋市港区千年 3-1-12） UACJ corporation (3-1-12 Chitose, Minato-ku, Nagoya-shi, Aichi 455-8670) 2 国立研究開発法人産業技術総合研究所 中部センター（名古屋市） Chubu Center, National Research Institute of Advanced Industry of Science and Technology (Nagoya-shi, Aichi)

* 責任著者E-mail: mori-hisashi@uacj.co.jp

受付日：2018年11月 1日＼cjkstart受理日：2018年11月26日
} 
·開発合金の圧延・鍛造・押出等の加工性評価

·高強度化・熱間割れ防止に向けた等温圧延技術の開発

・不純物や晶出物を分断微細化する連続ねじり鍛錬加工技術 の開発

·含有水素, 晶出物, 残留応力に対する革新的な定量評価技 術の確立

・航空機胴体部の部分カットモデルの試作

本報では，紙面の関係上，高強度・高勒性を示す最適合金設

計, 鋳塊の水素ガス低減と電磁擋拌手法による鋳塊組織微細化

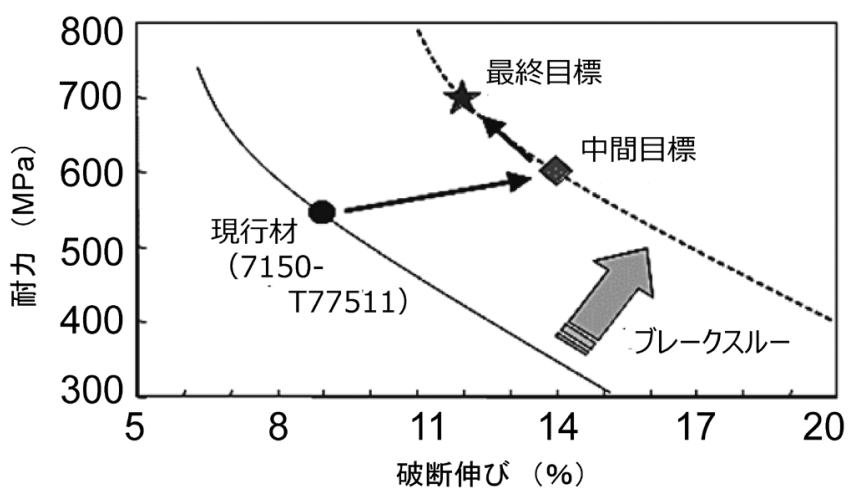

図1 本研究での高強度化の考え方
手法, 高強度化・熱間割れ防止に向けた革新的等温圧延技術の 開発，不純物や晶出物を分断微細化するねじり鍛錬加工技術の 開発, 残留応力に対する革新的な定量評価技術の確立に限定し て説明し，未紹介の研究については，別の機会に行う。

\section{3. 研究成果の紹介}

\section{1 高強度・高靭性を示す最適合金設計}

$\mathrm{Al}-\mathrm{Zn}-\mathrm{Mg}-\mathrm{Cu}$ 合金において, 亜鉛量の添加に伴い, 引張 強さおよび耐力は増加し, 伸びが低下する傾向が認められ る（図2 (a)）。引張特性に及ぼす銅およびマグネシウムの添 加量の影響を調べた結果, 図 $2(\mathrm{~b})$ に示すように高強度化を 示す組成範囲が認められた。また，耐応力腐食割れ性（耐 $\mathrm{SCC}$ 性）および破壊勒性の改善にはジルコニウムの添加が有 効であることを著者らが示しており，本研究においてもその 結果を検証している ${ }^{8)}$ 。これらより高強度・高勒性を示し, 耐 SCC 性に優れる候補合金として, Al-Zn-Mg-Cu-Zr系合金 を提案した。

\section{2 鋳塊の水素ガス低減方法と鋳塊組織微細化手法}

3.2. 1 鋳塊の水素ガス低減方法

アルミニウム合金の特性は鋳造時の溶解および溶湯処理工 程に影響され，溶解時に発生した水素ガス気泡は凝固時に残 留して鋳造欠陥となり, 強度に強く影響を及ぼすようにな

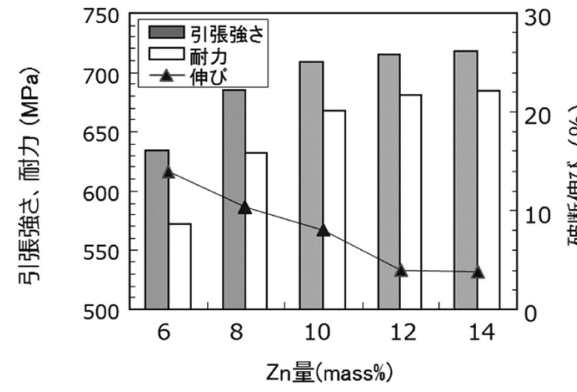

(a) 引張特性に及ぼす 亜鉛添加の影響

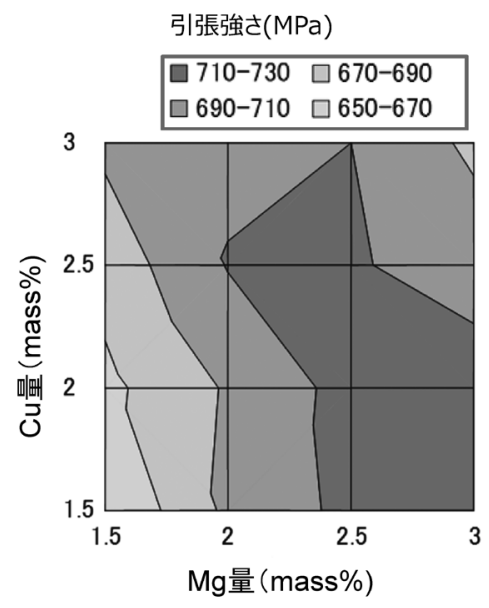

(b)銅及びマグネシウム添加 が引張強度に及ぼす影響

図 $2 \mathrm{Al}-\mathrm{Zn}-\mathrm{Mg}-\mathrm{Cu}$ 系合金の引張特性に及ぼす添加元素量の影響

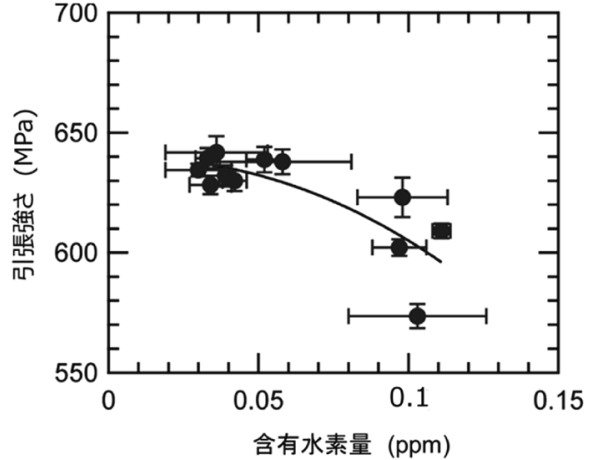

(a)引張強さと含有水素量との関係

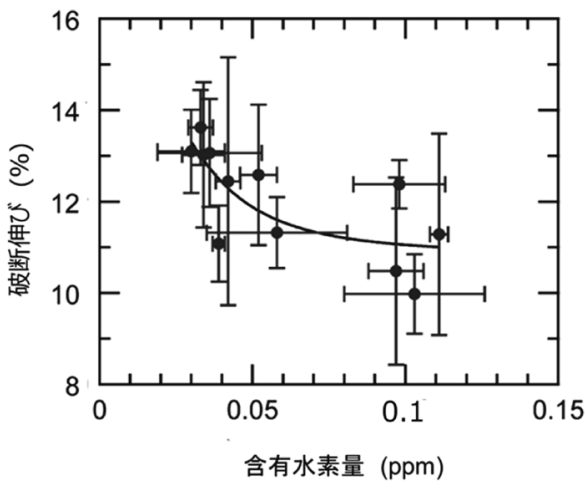

(b)伸びと含有水素量との関係

図 $3 \mathrm{Al}-\mathrm{Zn}-\mathrm{Mg}-\mathrm{Cu}$ 系合金の引張特性に及ぼす含有水素量の影響 


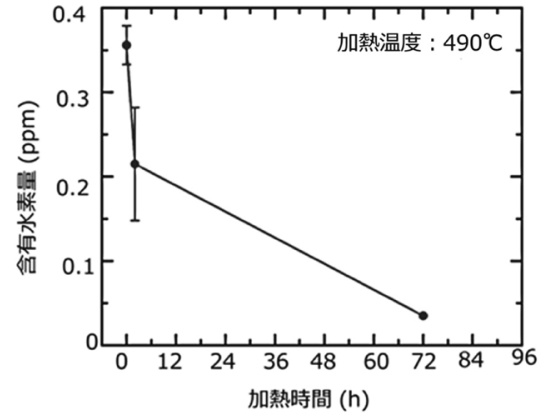

(a)加熱時間と含有水素量との関係

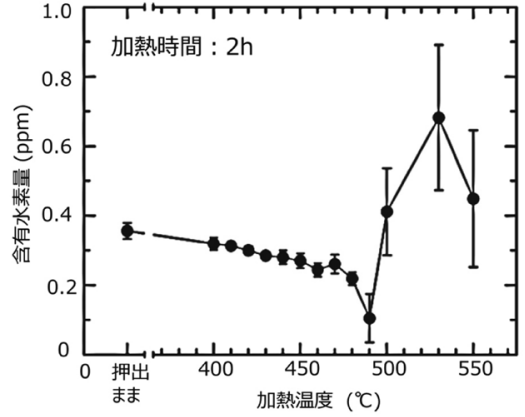

(b)加熱温度と含有水素量との関係

図4 $\mathrm{Al}-\mathrm{Zn}-\mathrm{Mg}-\mathrm{Cu}$ 系合金の真空雲囲気での加熱温度，保持時間と水素量との関係

る9)。図3に7075アルミニウム合金について調べた含有水素 量と引張強さおよび伸びの関係を示す。強度および伸びは, 含有水素量の増加に対して低下し, 含有水素量が $0.05 \mathrm{ppm}$ 以 下ではその影響度は少ない。このことから，開発合金におい ても汎用材と同様に水素の影響を受けるが, 強度および伸び に及ぼす含有水素量に臨界量があることを見出した。

含有水素量が機械的性質に及ぼす影響については, 変形中 に発生した転位の周りに集積した水素原子が応力場を緩和さ せることで，転位と障害物との相互作用を低下させ，強度お よび伸びに影響を及ぼしたと考えられるが，含有量に臨界量 が見られることなどから，さらに考察を進める必要がある ${ }^{10) 。 ~}$

引き続き, 脱水素化を図る目的で真空中において加熱処理 を試み，その効果を確認した。図4(a)に7075合金の水素量 と加熱時間の関係を示す。加熱温度および時間の増加ととも に水素量は減少する傾向が認められた。加熱に伴う平衡空孔 濃度の増加によりアルミニウム合金中の原子拡散が促進され, 含有水素が放出したと考えられる。しかし, 図4(b) に示すよ うに, 温度範囲を $500^{\circ} \mathrm{C}$ 以上, 特に固相線温度以上に加熱を 行えば, 水素が合金中にトラップされて増加する傾向が認め られた。固相線温度以上では, 生成する液相に水素が拡散し やすくなり，その後の凝固でそれらが材料中にトラップされ るためであると考えられる ${ }^{11)}$ 。また, 温度の上昇とともに液 相とともにトラップされる量が増加するためであると考えら れる。メカニズムについてはさらに考察が必要であるが, 脱 水素には, 真空中での加熱処理が有効であり, その加熱温度 については十分に注意を払う必要があることが確認された。

\subsection{2 鋳塊組織微細化手法}

展伸材の特性は鋳造材の初期組織に強く依存すると考えら れる。特に高強度・高勒性化には, 鋳造組織の段階から金属 組織を微細化しておくことも必要であると考えられる。一般 的に鋳造組織の微細化では, 微細化剤の添加で異質核生成を 利用した方法で行われる ${ }^{12)}$ 。

本研究では, 鋳塊の結晶粒および晶出物の微細化に対する 電磁摚拌手法の適用とその実用設備への設計に向けた取り組 みを進めている。電磁擋挥手法は, 昔から溶解炉のスラグ除 去法などに利用されていたが，結晶粒微細化にも有効である とされる ${ }^{13), 14)}$ 。

そこで, 電磁摚挥装置を鋳造装置に設置し, 開発合金の鋳 造に対する微細化効果の確認とその大型ビレットへの適用に ついて研究を進めている。小型試験炉で加熱したるつぼを, 電磁摚拌コイル内に設置し, 電磁擋拌を印加しながら凝固さ

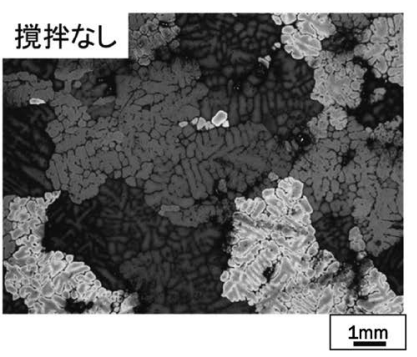

(a)電磁擋拌適用なし

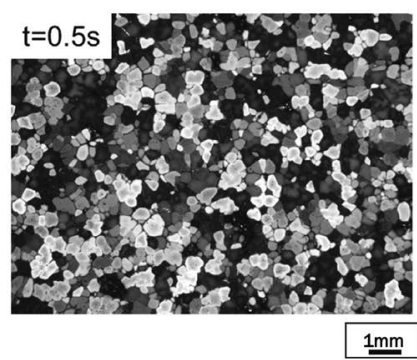

(b)電磁擋拌適用あり*
図 5 開発合金の造塊の金属組織（結晶粒）に対する電 磁擋拌手法の適用の効果

*攪拌は正転・逆転を繰り返すような形で印加して おり，時間 $(\mathrm{t})$ は反転周期を示している

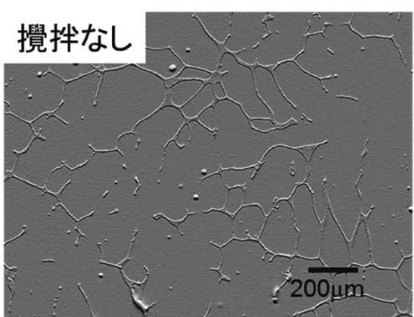

(a)電磁擋找未適用

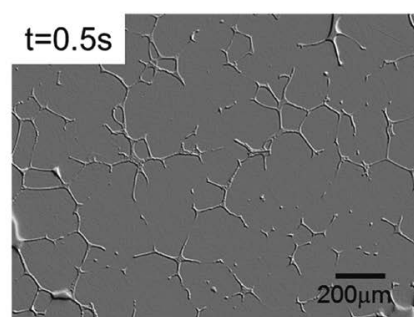

(b)電磁擋拌適用
図6開発合金の造塊の金属組織（晶出物）に対する電 磁摚汼手法の適用の効果

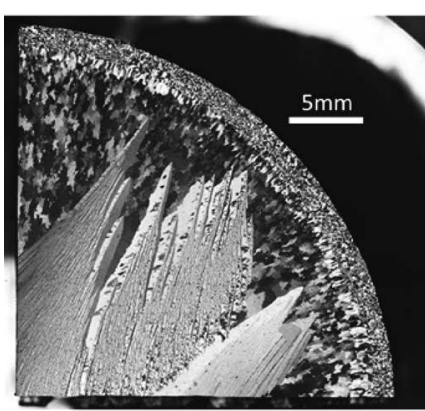

(a)電磁擋涛未適用

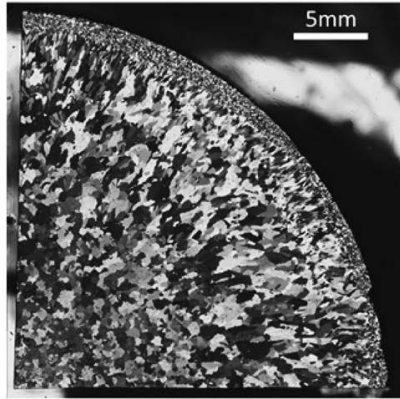

(b)電磁擋找適用
図7 小型鋳造炉で鋳造した時の開発合金ビレットの断 面金属組織に及ぼす電磁擋拌の印加の影響

せた試験材の金属組織を図 5 および図6に示す。電磁攪拌の 適用の有無と結晶粒および晶出物の状態を比較した結果, 結 晶粒は電磁擋拌を適用した場合には微細化した。しかし, 晶 


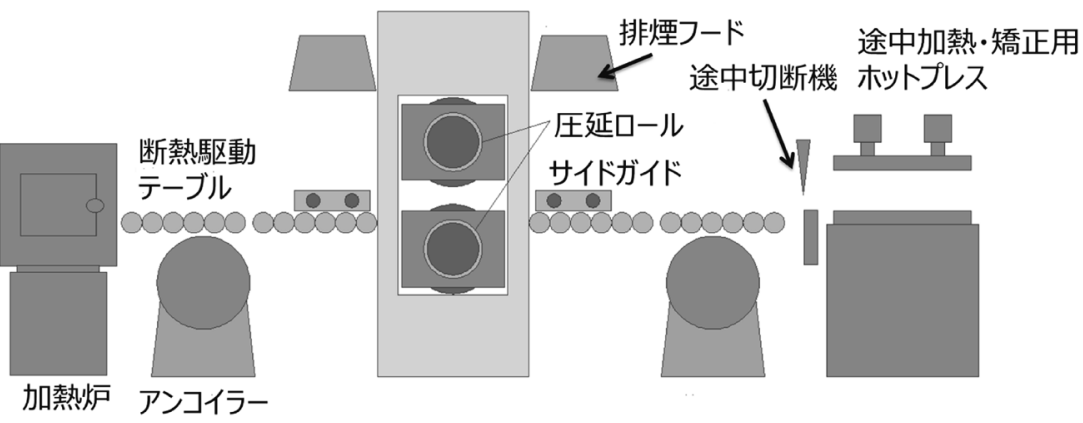

図8 本研究で開発した等温圧延装置の模式図

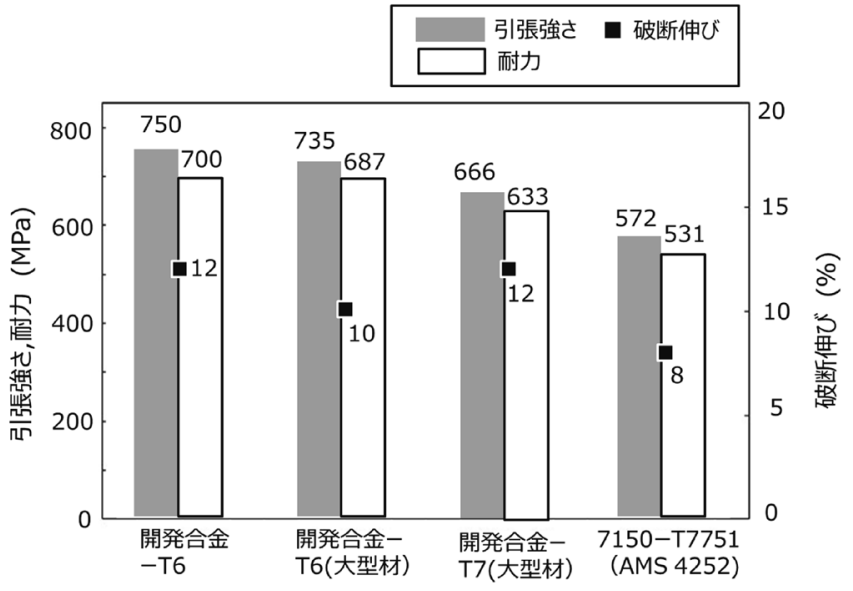

図 9 等温圧延加工機により作製した開発合金の T6 調 質における引張特性（7150材はAMS 規格）

出物への効果については, 結晶粒の微細化の傾向ほど顕著に は認められなかった。

また, 図7に, 小型連続鋳造機に電磁摚拌の装置を組み込 んで鋳造して得られた試験材の金属組織を示す。前述のるつ ぼ実験と同様に，適切な電磁擋拌を付与することで，鋳塊結 晶粒の微細化効果があることを確認した。

電磁擋拌による微細化のメカニズムとしては, 固相と液相 の電気抵抗值の違いに起因して, 固相と液相に働く電磁力が 異なり, 固液間で生じた相対運動による摩擦力で微細分断し たためであると考えられる。

現在，電磁摚汼の条件（トルク，抵抗力）等の基礎検討を 行い，大型ビレットの試作に対する電磁擋拌手法の適用への 課題の抽出を行っており,さらに各種擋汼パラメー夕を独 立・精密に制御できるような電磁摚找専用装置（電磁コイ ル）の試作を検討している。

\section{3 高強度化・熱間割れ防止に向けた等温圧延技術の開発}

高強度・高勒性アルミニウム合金の圧延板材を作製するた めには，板材の集合組織と安定なサブグレイン組織を得る必 要がある。それに対し，連続的に高い加工度が得られる手法 と圧延中の板面内の温度分布を一定にする手法が必要にな る。この検証に基づいて等温圧延装置を開発した。図8に等 温圧延装置の模式図を示す。装置には，圧延途中で板材を切 断できる装置, 温度分布の不均一性を防ぐための中間加熱装 置，ロールの均質加熱装置のそれぞれを設置している。

図9に開発合金を当該圧延機で圧延して熱処理を行い, 引張試験を行った結果を示す。開発合金では引張強さが $750 \mathrm{MPa}$ であり，伸びは $12 \%$ を示し，開発合金の幅広材（大

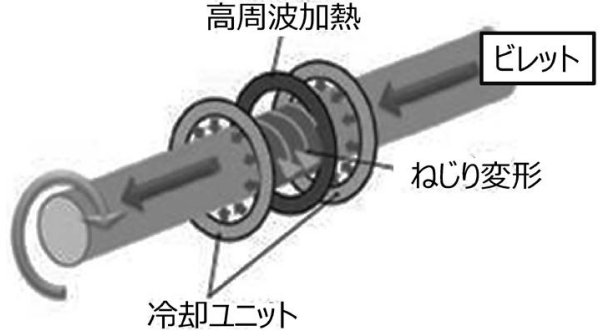

図10＼cjkstart連続ねじり鉞錬加工（CREO処理）の模式図

型材）では引張強さが $730 \mathrm{MPa}$ を示した。7150アルミニウ 厶合金 T775処理材の AMS (米航空宇宙材料) 規格 (強度 $570 \mathrm{MPa}$ ，伸び $8 \%$ ）に対し，強度は30\%程度高く，伸びは 規格を満足している。

等温圧延およびその後の時効処理により, 結晶粒の微細 化・繊維状組織化と晶出物の微細分散化したことが, 延性を 低下せずに高強度化を可能にしたと考えられる。また，別途 実施した耐食性評価では，良好な耐剥離腐食特性を示した。

\section{4 不純物や晶出物を分断微細化する連続ねじり鍛錬加} 工技術の開発

金属組織は加工ひずみの導入と熱処理により微細化する が，素材内部へ均一に加工ひずみを導入するのは困難である。

これに対してねじり負荷は素材内部へ均一にせん断ひずみ を導入することが可能であり, ねじり変形を押出加工に併用 して高性能化するなどの試みがなされている ${ }^{15)}$ 。本研究で は，連続ねじり鍛錬加工（CREO処理）16),17）についての検 討を行った。

\subsection{1連続ねじり鍛錬加工処理}

図10に連続ねじり鍛錬加工の模式図を示す。連続ねじり 加工は, 丸棒状のビレットに張力を与えると同時に, 局所 的に加熱しながら全体的にねじりトルクを与える方法であ る ${ }^{16)}$ 。この方法により，均一なねじりひずみを中心部にま で導入することができ，晶出物等が微細化できることを特徵 としている ${ }^{16)}$ 。これまでAl-Mg 合金の非熱処理型合金に連 続ねじり鍛練加工処理を行い, 結晶粒の微細化によって高強 度, 高延性化に効果があることが示されている ${ }^{16), 17)}$ 。本研 究では, $\mathrm{Al}-\mathrm{Zn}-\mathrm{Mg}-\mathrm{Cu}$ 系合金の熱処理型合金に適用し，ね じり鍛錬加工の効果と有効な処理工程について確認した。

3.4.2 連続ねじり鍛錬加工による高強度・高延性化の検証

図11に結晶粒および晶出物の形態に及ぼす連続ねじり鍛 錬加工の影響を示す。連続ねじり鍛錬加工後の結晶粒および 晶出物は, ねじり加工を行わない素材と比較して微細に分散 している状態にあることを認めた。面内せん断変形に伴うひ 
ずみおよび加熱により，結晶粒および晶出物が機械的に粉砕 されたとの報告 ${ }^{18)}{ }^{19)}$ があり，本研究で示された結果も妥当 であると考えられる。

次に，連続ねじり鍛錬加工を効果的に活用するため，均質 化処理と連続ねじり鍛錬加工の工程順について検証を行っ た ${ }^{20)}$ 。工程順では，鋳塊に均質化処理を行い，押出加工, 溶体化処理および時効処理を行う工程（ねじり鍛錬加工を行 わない場合；【1】とする)，均質化処理と押出加工の間にね じり鍛錬加工を行う事例（【と】する），鋳造後（造塊）材 に直接ねじり鍛錬加工を行い，その後，均質化処理，押出加 工，溶体化処理および時効処理を行う事例（【3】とする）を 検証した。

図 12 にねじり鍛錬加工の工程パターンおよびそれぞれの パターンで加工および作製した7150-T6材の試験材の引張試 験の結果を示す。引張強さおよび耐力は【1】<【2】<【3】であっ たのに対し，伸びは，【1】>【2】=【3】であった。これら結果 から，鋳塊に対して直接，ねじり鍛錬加工を行い，その後に 均質化処理を行う工程が，ねじり鍛鍊加工処理の効果を最も 引き出せることが示された。今後は，ねじり鍛鍊加工と金属 組織や疲労強度との関係を評価する。さらに，実用化に対す るねじり鍛錬加工の適用の検討にあたり，装置の大型化を検 証する予定である。

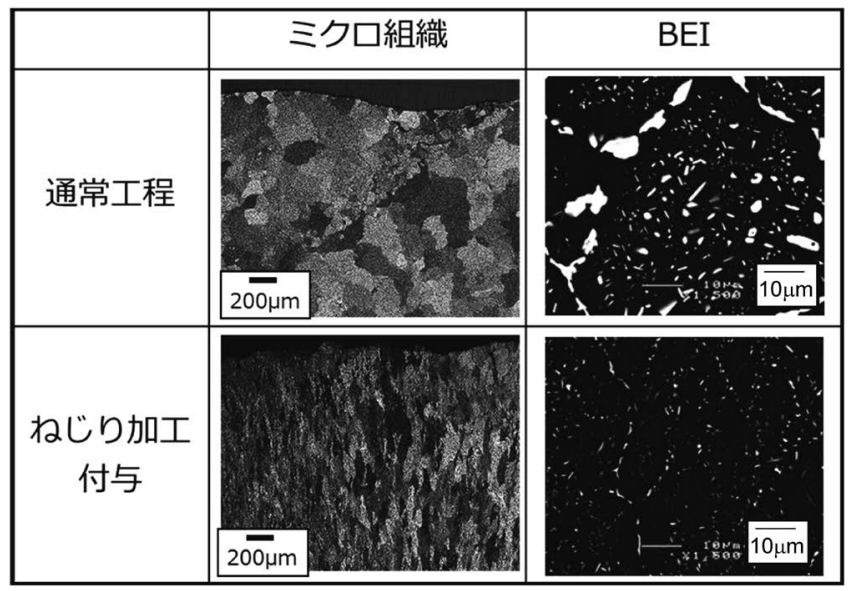

図 $11 \mathrm{Al}-\mathrm{Zn}-\mathrm{Mg}-\mathrm{Cu}-\mathrm{Zr}$ 系合金の結晶粒および晶出物の 形態に及ぼす連続ねじり鍛錬加工の影響
3.5 残留応力に対する革新的な定量評価技術

航空機部品は，板や部材を接着またはリベット結合で接合 して作製されていたが，最近では，厚板を使用し，厚板を切 削加工し，一体成形で作製されていることが多い。この方法 では，工程数およびコストの削減に効果があるが，切削中に 部材が変形して歩留まりが低下することがある。このような 切削加工中の変形を律速する要因に素材内部の残留応力の影 響が考えられる。一般的に残留応力測定は，X線法で行われ ている ${ }^{21)}$ 。X線法は汎用的であるが, 深さ方向に対する分布 測定は極めて困難である。そこで，厚板内部に対する表面お よび内部の残留応力分布を連続的に得る方法として深穴穿孔 法（DHD法）の適用が考えられる ${ }^{22)}$ 。本研究では, DHD法 を用いて厚板の定量的な残留応力分布を測定する方法の検討 を行っている。

3.5.1 DHD法による残留応力測定方法

図 13 にDHD 法による残留応力測定の手順を示す ${ }^{21)}$ 。最初 に基準穴を加工して穴径を求め，基準穴周辺に切削加工（卜 レパニング加工）を行い，トレパニング加工後の基準穴径の

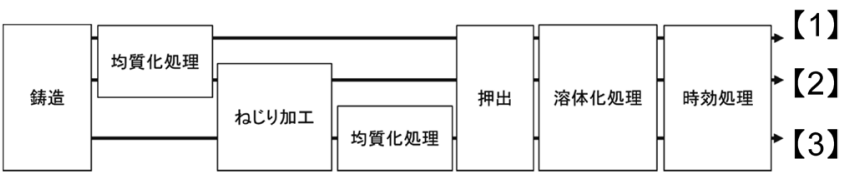

(a)ねじり鍛鍊加エの工程順の検証パターン

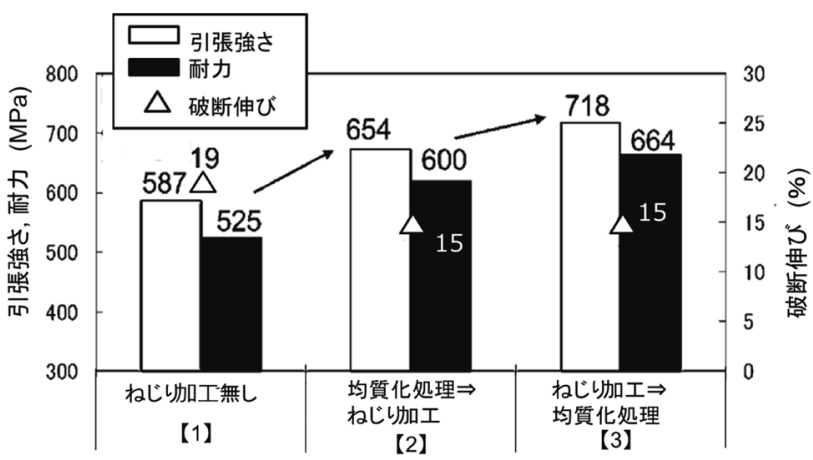

(b) 引張試験結果

図127150-T6材でのねじり鍛錬加工の工程順および各 方法で得られた材料の引張試験結果

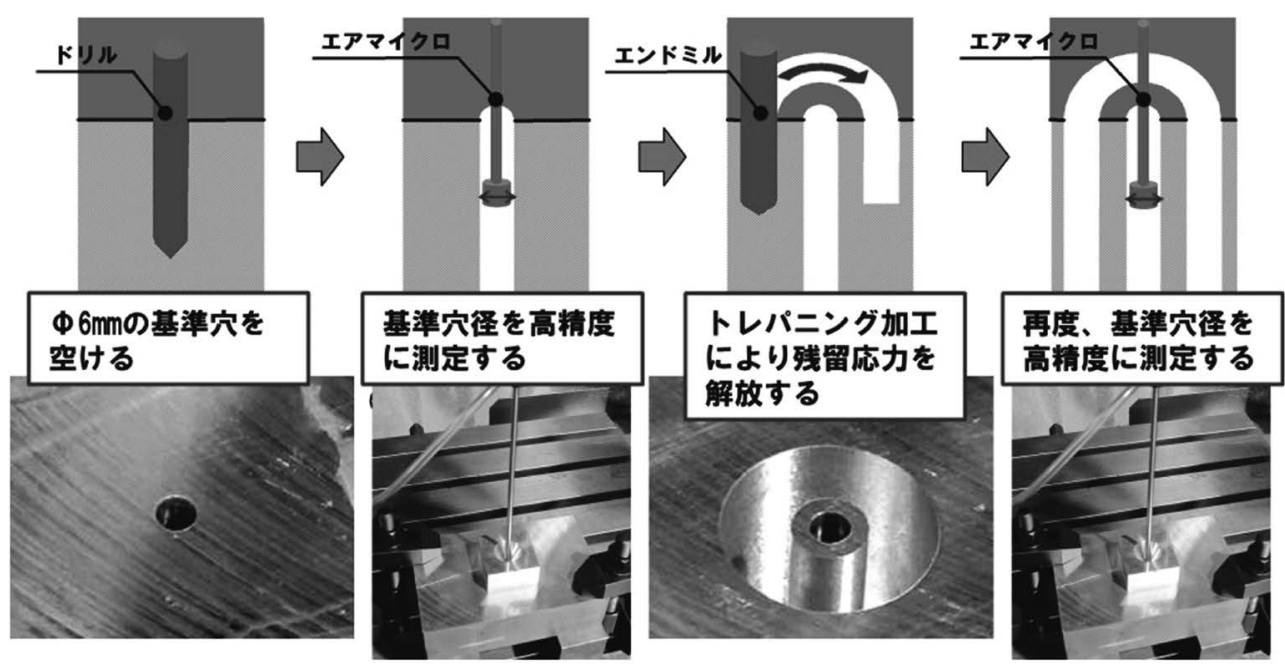

図13 Deep Hole Drill（DHD）法による残留応力測定の手順 


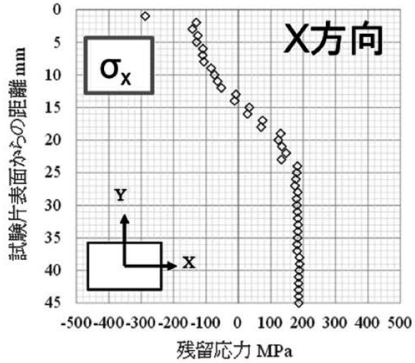

(a)T6材（x方向）

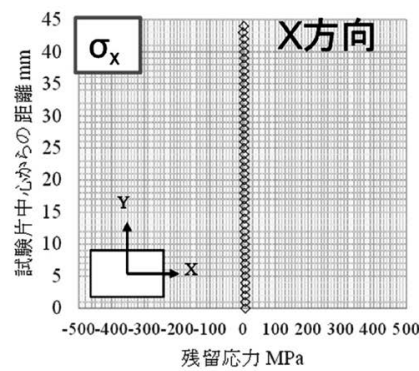

（c）焼鈍材（x方向）

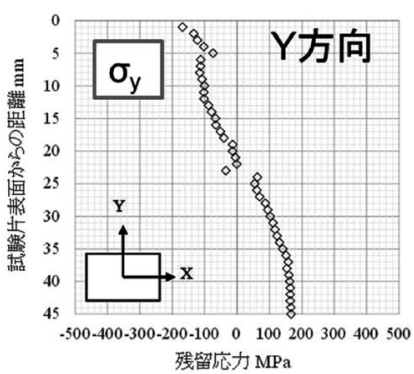

(b) T6材 (y方向)

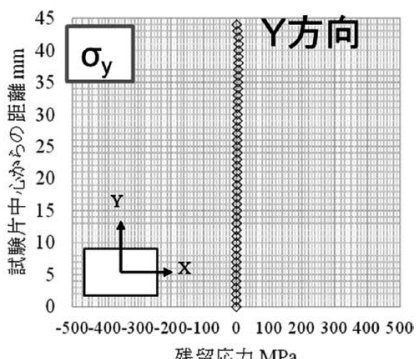

(d) 焼鈍材 (y方向)
図 14 DHD法で測定した7075-T6材および焼鈍材の残 留応力分布

穴径を求める。残留応力は, 基準穴径の差から変位を計算し, 弾性論から導出された理論解に代入して求められる。

\section{5 .2 残留応力分布の評価}

図 14 にHD法によって測定および計算した7075合金の厚 肉板材の $\mathrm{T} 6$ 材および焼鈍材の残留応力分布を示す。図 $14(\mathrm{a})$ および（b）のように，T6材では， $x$ および $y$ 方向に，厚み方 向に対する正負の分布が認められた。一方, 図14(c) およ び（d）に示すように，焼鈍材では，板厚方向に対する残留 応力の発生は認められなかった。T6材ではその焼入れ時の 熱応力による残留熱応力の発生が考えられる。一方, 焼鈍材 では，長期加熱に伴って残留応力の解放が考えられる。これ らのことから, 図 14 の残留応力分布の傾向は, 材料の処理 履歴に対応していると考えられ，測定結果は妥当であると考 えられる。現在, DHD法によって残留応力の分布が得られ ることがわかったが, 測定值の絶対值の精度について評価す る必要があり, 中性子回折法 ${ }^{23)}$ によって残留応力を測定し, 今回の結果を評価する予定である。

\section{4. 結言}

本研究では, 高強度・高勒性のアルミニウム合金およびそ のプロセス技術の開発を進めるために，合金設計，溶解鋳造 技術，プロセス技術，評価技術について検討した。これまで 得られた成果をまとめて下記に示す。

（1）高強度・高勒性および良好な耐食性を示す合金組成と して, $\mathrm{Al}-\mathrm{Zn}-\mathrm{Mg}-\mathrm{Cu}-\mathrm{Zr}$ 系合金を提案した。

（2）引張強度および伸びは含有水素量の増加とともに低下 するが, 含有水素量が $0.05 \mathrm{ppm}$ 以下では影響しない。また, 含有水素量は, 真空加熱を行うことにより拡散律速により放 出されて減少するが, 共晶温度以上に加熱すると水素が吸着 して増加することがわかった。

（3）電磁撹拌法の適用により結晶粒は微細化するが, 晶出 物の顕著な微細化効果は認められなかった。
（4）開発した等温圧延装置を用いて開発合金を圧延加工 し，その熱処理材に引張試験を行った結果，延性を維持しな がら高強度および耐食性を示すことを確認できた。

（5）連続ねじり鍛錬加工を行うことにより結晶粒および晶 出物が微細化することを確認し, ねじり鍛錬加工の適用は有 効であると考えられた。また，連続ねじり鍛錬加工の工程順 も重要であり，直接鋳塊にねじり加工を行い，その後に均質 化処理を行う工程が効果的であると考えられる。

（6）７075合金厚板の時効材および焼鈍材にDHD法を用い て残留応力測定を行った結果，材料の加工履歴に対応するよ うな残留応力の分布が認められた。

今後は, 実用化を目的として, 開発合金の大型材の鋳造技 術, 電磁摚拌手法の大型材製造への適用, 高精度の残留応力 測定技術開発, ねじり鍛鍊加工のさらなる検討を行い, 大型 部素材用の開発や, 航空機部素材の試作を行う予定である。 謝 辞

本研究は, 国立研究開発法人 新エネルギー・産業技術総 合開発機構（NEDO）の支援を受けて実施している。研究を 進めるにあたり，株式会社UACJ 林 稔氏，宮崎 悟氏， 菅野能昌氏, 則包一成氏, 皆川晃広氏, 三原麻未氏に実験 協力を得た。また株式会社神戸製鋼所 関係各位, 九州大学 戸田裕之教授, 岐阜大学 吉田佳典准教授, 山形大学 久米 裕二准教授, 新構造材料研究技術組合 (ISMA) 岸 輝雄理 事長, 堀谷貴雄氏に多大なる協力を受けた。各位に対し, 本 紙面を借りて心より厚くお礼申し上げます。

\section{参 考 文 献}

1) 高橋洋二, 大塚 敬, 原田昌彦, 関 恵子, 福塚祐子：日本物 流学会誌, 13 (2005), 123-130.

2) 杉本幸弘：溶接学会誌, 87 (2018), 66-70.

3) 金原 勲：日本船舶海洋工学会誌, 26 (2009), 2-6.

4) 森本哲也：溶接学会誌, 87 (2018), 62-65.

5) 中沢隆吉, 井原木幹成：Japan Forging Association, 45 (2014), $17-27$.

6) 宮木美光, 日野光雄, 江藤武比古 : 軽金属, 36（1986），697-704.

7）岩村信吾，箕田 正，吉田英雄；軽金属，60（2010）， 75-80.

8) 吉田英雄, 林 稔, 箕田 正, 則包一成: UACJ Technical Reports, 3 (2016), 74-91.

9）大塚良達：軽金属, 44 (1994)，461-471.

10) H. K. Birnbaum and P. Sofronis: Mater. Sci. Eng. A, 176 (1994), 191-202.

11）大西忠一：軽金属, 39 (1989), 235-251.

12）渡辺義見，佐藤 尚：軽金属，64（2014），157-163.

13) 三谷和久, 西山智彦, 沢田和一, 藤尾俊一: 鋳造工学, 69 (1997) 610-613.

14）西村 章, 川野 豊：軽金属, 33（1983），82-88。

15） 水沼 晋：塑性と加工, 50（2009）, 186-191.

16) K. Nakamura, K. Neishi, K. Kaneko, M. Nakagaki and Z. Horita: Mater. Sci. Forum, 503-504 (2006), 385-390.

17) K. Nakamura, K. Neishi, K. Kaneko, M. Nakagaki and Z. Horita: Mater. Trans., 45 (2004), 3338-3342.

18）久米裕二, 本橋雅和, 小橋 眞, 金武直幸: 塑性と加工, 57 (2016)，468-472.

19）久米裕二, 小橋 眞, 金武直幸: 塑性と加工, 48 (2007), 1007-1011.

20) 菅野能昌, 宇田川智史：軽金属学会第134回春期大会講演概 要, (2018), 49-50.

21）土肥 修, 佐藤恭博：日本機械学会論文集, 36（1970）, 14131420 .

22）三上隆男：検査技術，57（2017），18-25.

23）林 眞琴：日本機械学会論文集 A編，67（2001），363-369. 